\title{
Tapada da Ajuda (Lisbon, Portugal) Bronze Age pin
}

\author{
Ana Ávila de Meloa, João Luís Cardosob ${ }^{\mathrm{b}}$, and Alessandra Giumlia-Mair ${ }^{\mathrm{c}}$ \\ aMuseu Nacional de Arqueologia, Lisbon, Portugal; 'bepartamento de Ciências Sociais e de Gestão (DCSG), Universidade Aberta, Lisbon, Portugal; \\ 'AGM Archeoanalisi, Merano, Italy
}

\begin{abstract}
A pin made of a copper-based alloy, found at Tapada da Ajuda (Lisbon, Portugal), a site dated to the beginning of the Late Bronze Age, was analyzed by X-ray fluorescence (XRF) spectroscopy and examined by microscopy. The results of this study and the unusual manufacturing technique of the pin are presented and discussed in this paper. Typology and production technique of this object seem to indicate a Central European origin.
\end{abstract}

ARTICLE HISTORY

Received 9 July 2016

Accepted 22 August 2016

\section{KEYWORDS}

Archaeology;

archaeometallurgy; LBA;

manufacture; pin; Portugal;

technology; XRF

\section{Introduction}

The construction of a rugby field in 1982, in the campus of the Instituto de Agronomia (Institute of Agronomy, Tapada da Ajuda, Lisbon, Portugal), revealed the remains of an archaeological settlement with a large single archaeological layer, containing bones, shells, ceramics, lithics, and other artifacts. An emergency archaeological survey and excavation were performed by one of the authors (JLC) in 1983. Due to the importance of this site and the delay in the rugby field construction, the archaeological excavations continued until 1987.

Although the rampart made for the rugby field construction destroyed part of the settlement, the remains of structures were clearly identified. This unfortified settlement is located on a smooth slope (Fig. 1) facing the Tagus estuary in the south.

The only excavated housing structure showed a 6-m long oval hut, with a basement of basaltic blocks (Fig. 2).

The five radiocarbon dates obtained for the site, after calibration, indicate the 13th-12th centuries cal BC, in other words, the transition from the Middle Bronze Age to the early period of the Late Bronze Age $[1,2]$. This was confirmed by an, still unpublished, AMS radiocarbon date, carried out on a mandible fragment of Bos taurus:

Wk-35559-2932 $\pm 25 \mathrm{BP}$ that for $95.4 \%$ probability corresponds to the calibrated interval 1259-1046 cal BC, using the OxCal Program 1.7 [3].

This Bronze Age settlement, a small village with more huts similar to the one that was excavated, located in the fertile basaltic soils of the Lisbon's region (Fig. 3) had, as several other villages in this area and period, an economy based on intensive agriculture, namely on cereal production.

The enormous amount of denticulate flint flakes used in wood sickles corroborates this interpretation. The vicinity of the Atlantic Ocean and its location near the Tagus estuary favored the contacts - both regional and transregional ones with northern and southern regions, but also with the interior, and, on a transregional level, between the Atlantic and the Mediterranean.

During the archaeological excavations in 1984 two metal artifacts were recovered: a slag fragment and a small hoop. They were analyzed by means of energy dispersive X-ray fluorescence (EDXRF). Several measurements were made on different areas of each object and the results showed that they were bronzes. The high tin contents (around 20\% Sn) obtained from these measurements were probably due to corrosion and redeposition of Sn oxides on the surface. These results have already been published [4].

Later on, in 1987, during the last archaeological campaign on this site, a pin and several other bronze artifacts were recovered. Among these the pin represents the most interesting object, because of its typology.

\section{Material and typology}

The shape of this pin is typical for the types "Lochhalsnadeln mit rundem Schaftquerschnitt und geschwollenem Hals mit gerundet doppelkonischem Kopf". There are very similar examples from Sitzendorf and Potzneusiedel in Austria and Dunaújvaros (grave 220 or 380; grave 578, Lochhalsnadeln mit rundem Schaft und geschwollenem Hals) in Hungary $[5,6]$. The type seems to come mainly from Austria, south of the Danube in the regions of southern Low Austria, Burgenland, Carinthia and Styria, but examples are found in almost all groups of the Tumulus Culture of the Middle Bronze Age (ca.1600-1200 BC), in Oberösterreich, Bavaria, Bohemia and Hungary, with single finds as far as in Württemberg and in the Middle Rhein territory, in the North up to Silesia and the west Baltic, in the East in Transylvania and in the South in Northern Italy and Slovenia [7].

Together, the two corroded fragments (shaft and head) of this undecorated metal pin are $14.8 \mathrm{~cm}$ long. The diameter of the head is $1.1 \mathrm{~cm}$ and the diameter of the swollen upper shank with circular section is $0.86 \mathrm{~cm}$. The pin shows a 


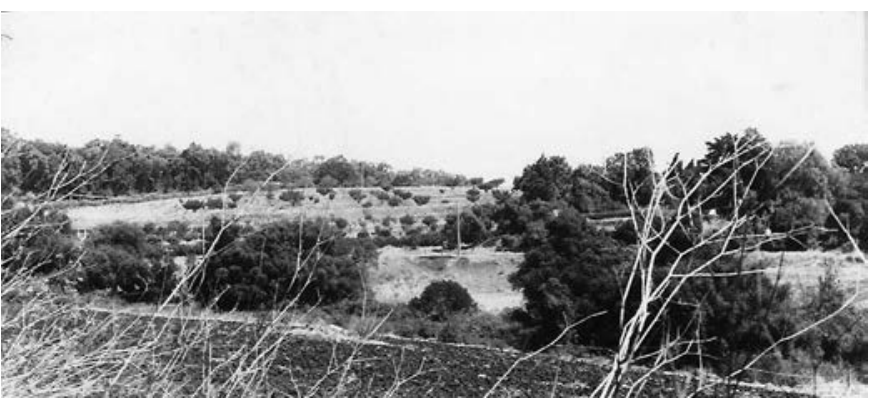

Figure 1. Tapada da Ajuda Bronze Age settlement. The excavation area is in the center of the figure. Photo by J. L. Cardoso.

transverse and not quite central perforation at the thickest point. The total weight of the two fragments is $11.8 \mathrm{~g}$ (Fig. 4).

Prehistoric metal pins, either recovered on archaeological excavations or found in hoards, are quite rare in Portugal. The earliest artifacts are assigned to Late Bronze Age. There are two gold objects and the rest are, with all probability, copper alloys; however, most of them have never been analyzed.

The pin from Tapada da Ajuda (Lisbon, Portugal) is, up to now, one of the two examples in Portugal that was recovered from an identified, radiocarbon-dated archaeological context and analyzed. In the last decade of the 20th century, Vilaça also recovered a pin during archaeological excavations in Alegrios (Idanha-a-Nova, Central Portugal), a Late Bronze Age settlement. In the publication the author stressed the rarity of the artifact in the Portuguese territory; its chemical composition analysis indicates a bronze with high tin content [8].

Most of the metal pins were discovered in the late 19th or early 20th centuries and, although the records state that they were found in settlements, we do not possess much more information and do not know their archaeological contexts.

The gold pin from Penha Verde (Sintra, Portugal) was found in 1957 in a settlement, during archaeological excavations performed by Zbyszewski and Veiga Ferreira [9]. This site has a Chalcolithic date; however, archaeological excavations identified a Late Bronze Age occupation, with parallels in some fortified settlements of the Estremadura region (for instance, Penedo do Lexim and Pragança).

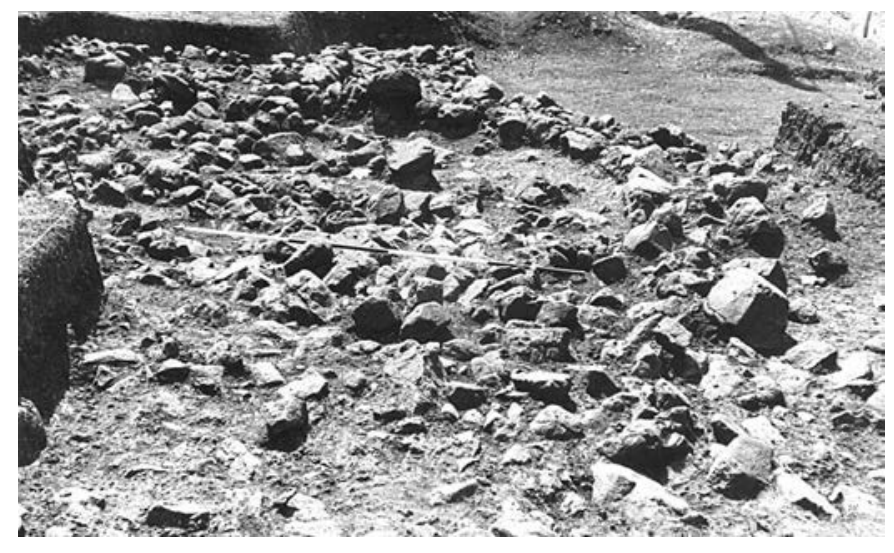

Figure 2. The basement of an oval hut, made of basaltic blocks. Photo by J. L. Cardoso.
The gold pin from Penha Verde was found in Casa 2 (Hut 2), which has a Late Bronze Age occupation. This important find, associated with Late Bronze Age ceramics, confirmed the radiocarbon dating of this site. The radiocarbon date calibrated by means of INTCAL O4 program established the settlement's occupation between 1000 and $820 \mathrm{cal} \mathrm{BC} \mathrm{[10].}$ This pin, with a flat conical button head, is similar to a gold pin from Mealhada (Aveiro, Portugal) bought in 1921 by the first director of the Museu Nacional de Arqueologia (National Museum of Archaeology, Lisbon) [11].

There are other Bronze Age metal pins that belong to the collections of the Museu Nacional de Arqueologia. They were recovered mostly in settlements, at the end of the 19th or the beginning of the 20th century. The main problem is that many of the recovered artifacts are not complete and the majority may be classified either as needle or as a pin shaft. Nevertheless, in the museum's collection there are also four complete Bronze Age metal pins, all found in settlements: two from Pragança (Cadaval), a settlement located also in the Portuguese region Estremadura. One of them was recently qualitatively analyzed by EDXRF, and it was identified as bronze [12].

In the Museum's collections there are two further Bronze Age metal pin fragments (head and shaft fragment) from Abrigo das Bocas (Rio Maior) in the Portuguese Estremadura region, found during archaeological excavations in a cave, in 1937. In 1994 the two pin fragments were published, and interpreted as pin fragments or spikes. One of them was analyzed, and the EDXRF results showed that it was a copper-tin alloy [13].

There are two more pins from northern Portugal, i.e., from S. Miguel-do-Anjo (Arcos de Valdevez) and Mateus (Vila Real). They were found in 1893 and 1905. In 1893, Félix Alves Pereira excavated in S. Miguel-do-Anjo, Arcos de Valdevez castle, a hut with ellipsoidal plant, and recovered some metal finds that can be dated to the Bronze Age: the pin (no. 11974), slag fragments, a hoop, and a ring. The pin has a sharp point, a shaft with circular section, and a round head. The upper part of the shaft is decorated with circles. This piece is very similar to a pin from Santa Lucia di Tolmino/Most na Soçi (Narodni Muzej, Ljubljana) [14, 15]. The second pin was found in 1905 in Mateus, Vila Real, and has a flat twisted head and a thin and longer shaft. Both pins are probably to be dated to the Late Bronze Age.

Four complete bronze pins have been identified in Central Portugal. One of them was recovered by Vilaça during the excavations at LBA Alegrios settlement, two more come from Baiões (Viseu) and a further one from Santa Luzia (Viseu), now belongs to the collections of the Museu do Seminário Maior, Viseu [16]. The four pins can be attributed to different typologies: two (Alegrios and Santa Luzia pins) belong, according to Heynowski [17], to the "Rahmenkopf" pin type, and have an identical parallel, the third is a spiral-headed pin; and the fourth is characterized by a cylindrical shaft and a round head. As they have a different typology, they must be considered unique pieces, with the exception of the three very similar "Rahmenkopf" type pins from Alegrios (Idanha-a-Nova), Pragança (Cadaval), and Santa Luzia (Viseu). The "Rahmenkopf" type, according to Heynowski, is related to the Middle Bronze Age "Schnurkeramische Kultur" 


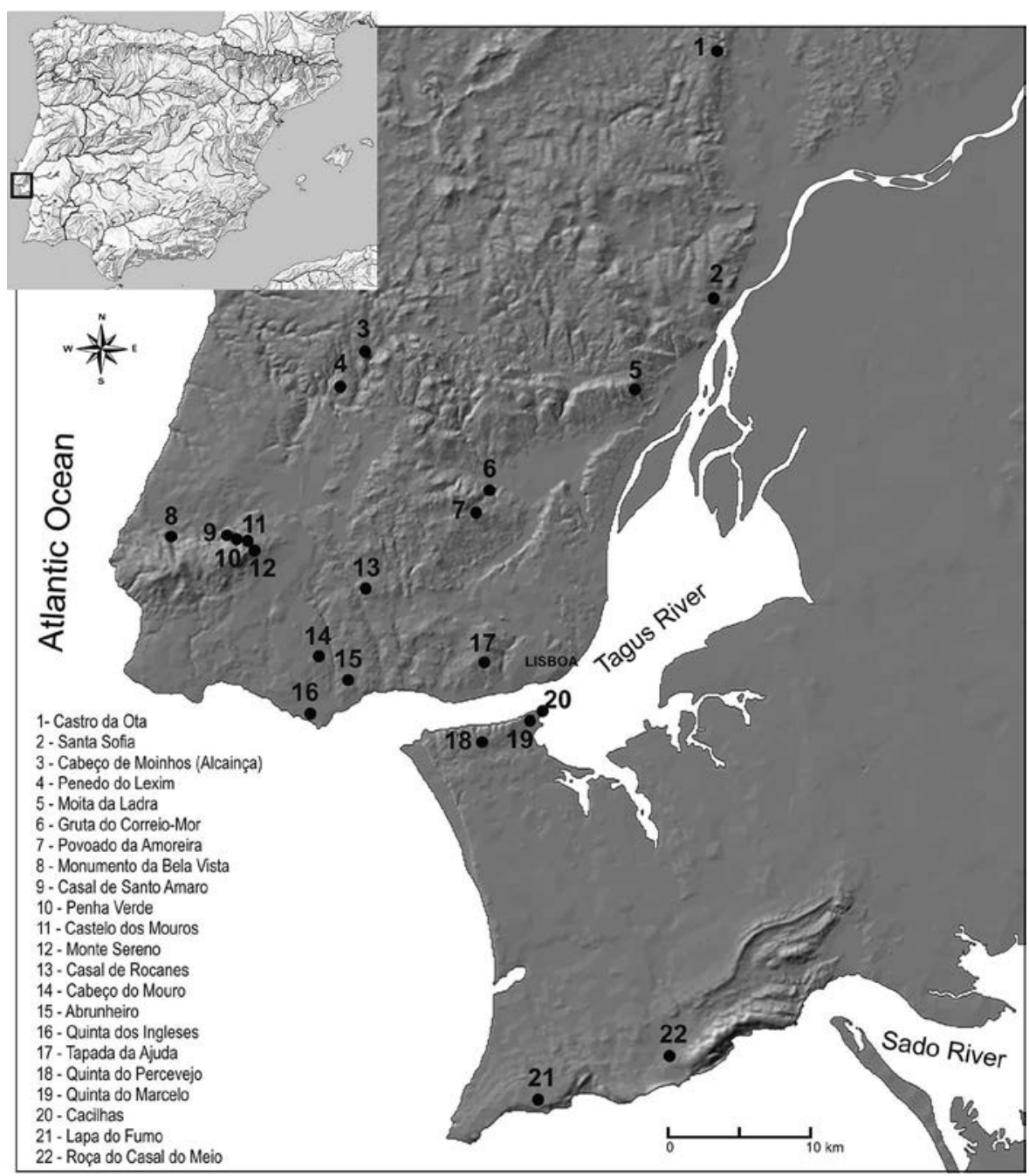

Figure 3. Main archaeological sites from the Late Bronze Age of the Lisbon region. After J. L. Cardoso.

well represented in central Europe [18]. The other bronze pin from Pragança (no. 2005.10.25), according to Heynowski, also has parallels with the central European Middle Bronze Age "Brillennadel" [19]. In the collections of the Musées de Chambéry (Lac du Bourget, Switzerland), there is a further similar example [20].

The mentioned Bronze Age pins - the complete pins, excluding the two gold examples - can be related to findings in the Eastern Alps and Austria, and might be imported items with the exception of the Alegrios piece, which according to Vilaça is apparently unfinished, and therefore might have been of local production [21]. Consequently, we assume that this type of Bronze Age metal artifacts found on Portuguese territory, including the pin from the settlement of Tapada da Ajuda, can be directly connected with Central and Eastern Europe. The examination of the metal pin from Tapada da Ajuda is therefore of utmost importance in order to define its origin.

\section{Method of analysis and procedure}

For the study on the pin, around 10 analyses by X-ray fluorescence (XRF) spectrometry have been carried out on each fragment with the aim of identifying the composition of the metal and comparing it with the composition of the nail coming from the same archaeological context and the same layer. Further goals were the determination of the production technique and the finishing processes of both objects.

XRF spectrometry [22] has been employed on several kinds of archaeological materials for several decades with good results [23-25]. Therefore, a detailed description of the method is not necessary and only a brief outline is given here. The fluorescent X-rays created by the X-rays source (i.e., the head of the system) hit the sample, and the electrons in the inner orbital shell of the atoms of the object to be analyzed are dislodged. One of the electrons from one of the higher energy orbital shells fills the vacancy left in the inner orbital shell. The electron drops to the lower energy state and releases a fluorescent X-ray which is characteristic for one specific element and is identified by the system. Each element present in a sample produces a set of fluorescent X-rays that allows the simultaneous determination of the material's composition. Numerous past analytical experiences showed that the measurements coincided well with the reference samples. In the past many analyses carried out by atomic absorption spectrometry (AAS) and XRF on the same samples have been compared, and over $90 \%$ of the XRF results were well within $+20 \%$ of the corresponding AAS results. The calculated 


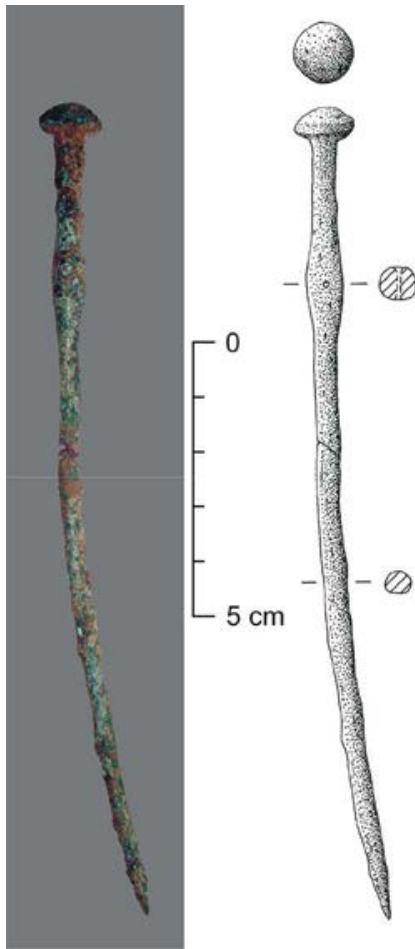

Figure 4. Tapada da Ajuda bronze pin. Photo by A. Giumlia-Mair. Drawing by B. L. Ferreira.

correlations for tin and lead, two of the most important alloying elements, range from 0.84 to 0.97 .

The XRF spectrometry equipment employed for this study was especially developed for the study of cultural heritage materials. It consists of the $\mathrm{X}$-rays source, mounted either on a support with devices that control its stability and position or on a slide, depending on the performance required, a large transformer equipped with a stabilizer, and a laptop computer. The head of the XRF system is equipped with a collimator that allows to change the diameter of the beam, as required by the characteristics of the object and its conservation, a laser pointer, marking the exact spot on the specimen to be measured, and a device to keep the exact distance from the sample. An acoustic signal confirms that the distance is correct before each measurement (within the acceptable span of $\pm 0.1 \mathrm{~mm}$ ). The position of the beam must be the same throughout the measuring session and perfectly vertical to the sample. The various parameters can be carefully controlled and this allows a precise calculation of the composition. The comparison of the measurement taken on the samples and those taken on the known standards is therefore quite reliable.

The standards employed during the measurements are extremely important for the quality control of the data, and are measured at the beginning of each day, whenever the equipment is switched off, and also routinely every couple of hours, if the session is very long. In this way possible drifts that may have occurred because of change of temperature, humidity, or other parameters that can affect the performance can be monitored and taken into account by the calculation, to achieve reliable data.

For this research various standards with different compositions were used: copper containing single elements, such as $5 \% \mathrm{Sn} ; 1 \% \mathrm{As}, \mathrm{Sn}, \mathrm{Ag}, \mathrm{Fe}, \mathrm{Pb}$, and $0.5 \% \mathrm{As}, \mathrm{Ag}, \mathrm{Fe}$, respectively. Further, standards with the following compositions have been employed: $1 \% \mathrm{Sn}, \mathrm{As}, \mathrm{Fe}, \mathrm{Pb}$ in $\mathrm{Cu} ; 1 \% \mathrm{As}, \mathrm{Sn}, \mathrm{Ag}, \mathrm{Sb}, \mathrm{Fe}$ in $\mathrm{Cu} ; 1 \% \mathrm{Sn}, \mathrm{Ag}, \mathrm{Au}$, As in $\mathrm{Cu}$.

The copper-based standards also allow the calculation of interference effects, such as enhanced results for iron in a copper matrix or similar phenomena. Each measurement typically requires 10-15 minutes, but, if necessary, the time span can be longer, while for the first explorative analyses the measurement time can be shorter. A longer measurement is always necessary when the area to be analyzed is particularly small, as in the case of the pin-shaft and more signals have to be collected to obtain sufficiently precise data.

The pin was first autoptically examined. In the second stage, devices with different magnifications were employed. Aim of the examination was the determination of the conservation and in particular the individuation of the best areas for analytical measurements. In this way traces of tools and/or signs of wear can also be recognized.

The objects and their details were photographed, both with a digital camera provided with two macros and by microscope with different magnifications (especially $\times 50$ and $\times 200$ ).

\section{Discussion of results}

The pin is covered with a relatively rough patina. As the microscopic examination showed, some internal corrosion is present too. In this case we have to be aware that the percentages of some elements identified by XRF, in particular tin, might not correspond to the original composition. This problem is less concerning in the case of arsenic that, being nobler than iron, would not be greatly affected by corrosion as long as some iron is present in the alloy [26].

The means of the measurements carried out on the shaft of the pin showed that the metal is bronze with a relatively low tin content of around $4 \%$, and an arsenic content of $1.2 \%$. This composition is generally, in most European countries, indicative for the Middle Bronze Age, to which this pin shape can be also stylistically dated. In the first part of the Middle Bronze Age there was a transition from a metallurgy employing arsenical copper alloys to alloys with tin (i.e., bronze was introduced as the mean alloy in this period), and it was quite common to have items containing both tin and arsenic. This is for instance the case at Gournia, Crete, where in most objects of this date both metals are found $[27,28]$. The arsenic might be due to the recycling of scrap metal or perhaps it was added to the copper because of its advantageous properties. This metal increases the hardness of copper and has also good deoxidizing properties. It is also just possible that the metal artisans simply continued to use it in combination with tin, just because of the previous long metallurgical tradition based on natural or intentional arsenical copper alloys.

A second batch of analyses carried out on the head of the pin confirmed the previous data, albeit with a slightly higher tin content.

The microscopic examination of the pin showed an interesting detail that allows the identification of the manufacturing technique used for its production. 
Along the shaft, where the upper rough corrosion layer is missing and the metal is only covered by thin and compact noble patina, there is a seam that begins slightly under the hole in the thickened part, and runs down the shaft, before disappearing again under the rough corrosion layer.

The seam line can be also discerned with a 10 magnification, where the patina is thinner.

The existence of the seam down the length of the pin shaft demonstrates that, to obtain the central hole in the center of the thickened part of the shaft, the metal artisan employed an unusual procedure (Figs. 5-8).

The pin's shaft is made out of a rolled up, elongated piece of bronze sheet. The shaft was hardened and shaped by hammering, but the original rolled up sheet is still recognizable at the point and at the break.

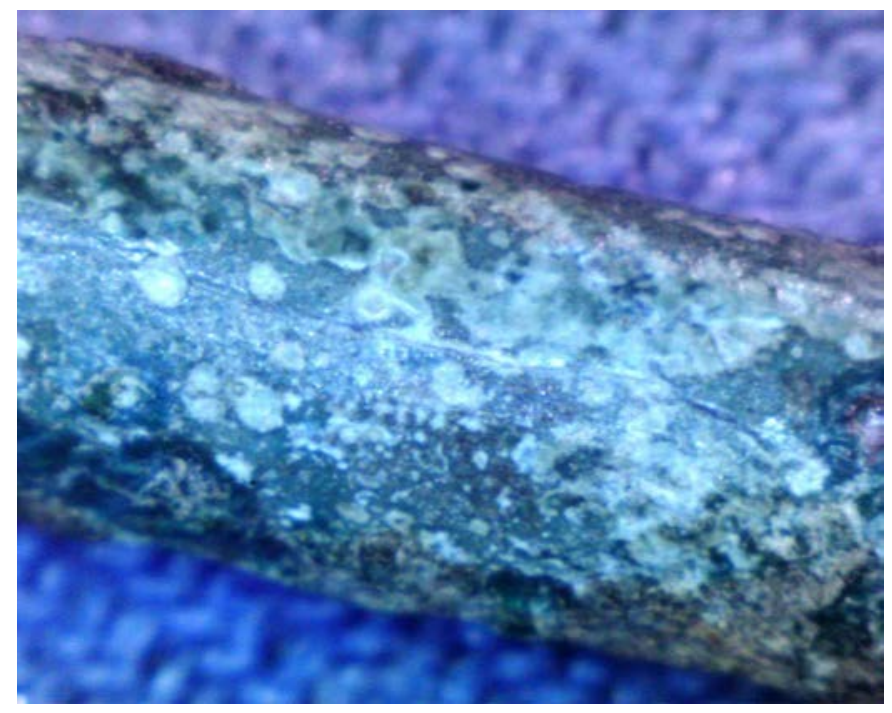

Figure 5. $50 \mathrm{X}$. Detail of the pin shaft, showing the seam that from the hole in the thickened part runs down the entire shaft. Photo by A. Giumlia-Mair.

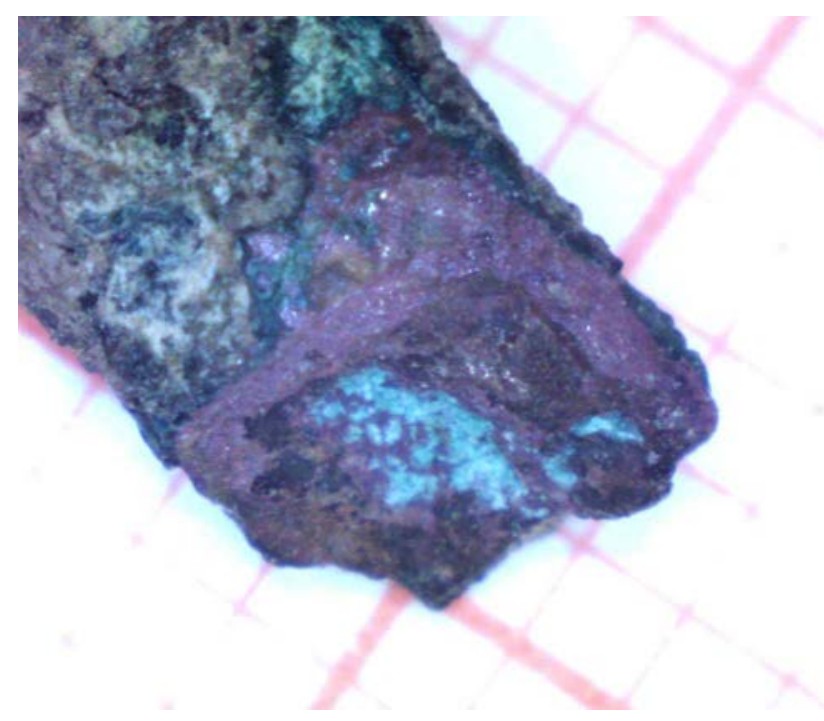

Figure 6. $50 \times$. Micrograph showing the break on the pin shaft. The shaft consists of a rolled up piece of sheet, hardened by hammering. Photo by $A$. Giumlia-Mair.

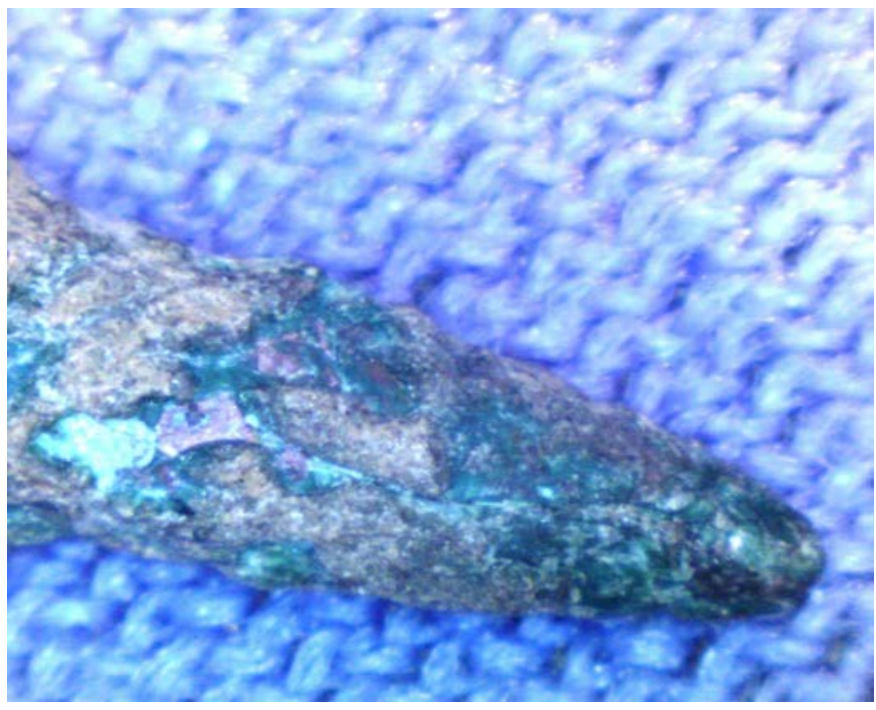

Figure 7. $50 \mathrm{X}$. Detail of the pin's point showing the seam line resulting from the rolled up sheet. The point was shaped and hardened by hammering. Photo by A. Giumlia-Mair.

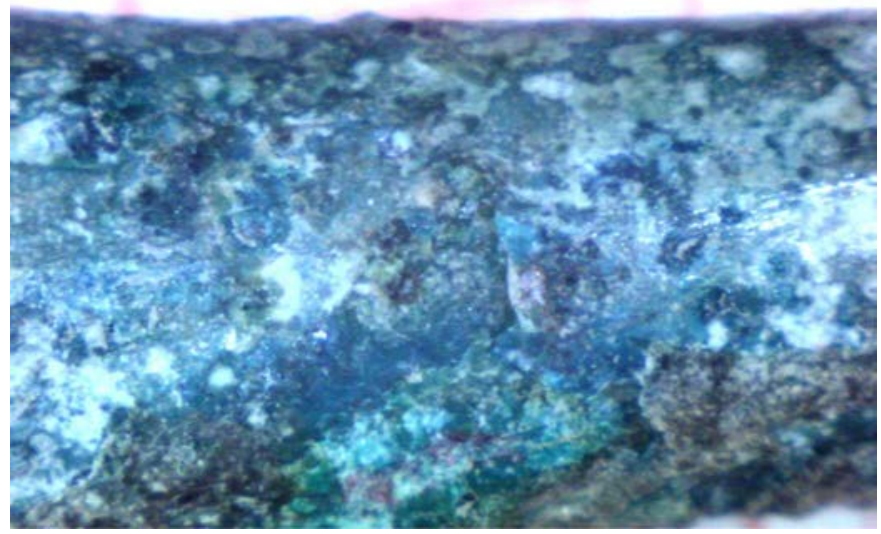

Figure 8. Detail of the shaft under the thickened part, showing the line left by casting the head on the pin. Photo by A. Giumlia-Mair.

The head was modeled in wax directly on the shaft, and the hole was filled with the clay used for the mold. The casting was obtained by using the common lost-wax process.

The line left by casting the head on the shaft is also visible as a roughly vertical, very irregular line (at the center of the photo in Fig. 8)

After the pouring and cooling of the metal, the casting funnel was removed with a chisel from the head of the pin, and the head was finished by hammering. The hole in the thickened part of the shaft was cleaned from the clay, and the casting skin removed with pumice stone or a similar material. Finally the entire pin was polished with finer abrasives.

To our knowledge, this manufacturing process has never been documented before.

It is important to stress that, in the West of the Iberian Peninsula, the lost wax technique is only documented in the 
last period of the Late Bronze Age, and, as far as we know, it was only employed on gold jewelry [28].

\section{Conclusions}

The composition and the typology of the pin are compatible with a Middle Bronze Age date, i.e., slightly older than the period to which the site in which the pin was found is dated: the chronometric results point to a dating of the site in the Late Bronze Age.

The type seems to come from Central Europe, but it is obviously impossible to know how it arrived to the westernmost part of the Iberian Peninsula. From this area no similar items are known. On the contrary, the best comparative examples for the pin are found in Central Europe.

The pin is a composite object, consisting of a separately worked shaft, made of a rolled up bronze sheet, that underwent a consolidating and hardening process by hammering, and a cast-on head, showing the hole, which is characteristic for this type of personal decorative object. To our knowledge no documentation of examples produced with this particular manufacturing process exists; however, it is quite interesting to note that the pin from Hadleigh [30] seems to show a similar kind of break, immediately under the thickened part of the shaft. This would be the weakest point, in case the head of the pin had been cast on the shaft, like the example discussed in this paper.

The use of the lost-wax process to cast the pin's head on the shaft also seems to indicate that this is an imported item, as this method was not used by the local populations until the end of Late Bronze Age/beginning of the Iron Age, and its earlier use in this region is only documented on gold jewelry.

\section{References}

[1] Cardoso, J.L. O povoado do Bronze Final da Tapada da Ajuda, $A$ Idade do Bronze em Portugal: discursos de poder, Lisboa: IPM, MNA, 1995; 49

[2] Cardoso, J.L. Between the Atlantic and the Mediterranean: The Late Bronze Age around the Tagus estuary (Portugal). Economic, social and cultural aspects. Rivista di Scienze Preistoriche 2015, 65, 149-170.

[3] Bronk Ramsey, C.; Dee, M.; Lee, S.; Nakagawa, T.; Staff, R.A. Developments in the calibration and modeling of radiocarbon dates. Radiocarbon 2010, 52 (2-3), 953-961.

[4] Cardoso, J.L.; Rodrigues, J.F.; Monjardino, J.; Carreira, J.R. A jazida da Idade do Bronze Final da Tapada da Ajuda. Revista Municipal 1986, Série II, 15, 3-18.

[5] Rihovsky, J. Die Nadeln in Mähren und im Ostalpengebiet, Prehistorische Bronzefunde; 1979, XIII-5, 24-26, Tafel 5, 83.

[6] Rihovsky, J. Die Nadeln in Westungarn I, Prehistorische Bronzefunde XIII-10; Beck'sche Verlagsbuchhandlung: München, 1983; 7, Tafel 3, 33; 34.

[7] Rihovsky, J. Die Nadeln in Mähren und im Ostalpengebiet, Prehistorische Bronzefunde; München, 1979, XIII-5, 25-26 and 31.

[8] Vilaça, R. Aspectos do Povoamento da Beira Interior (Centro e Sul) nos Finais da Idade do Bronze. Lisboa: IPPAR; 1995; 351

[9] Cardoso, J.L. A ocupação do Bronze Final do Povoado Pré-histórico da Penha verde (Sintra). Estudos Arqueológicos de Oeiras 2010/2011, $18,579-590$.
[10] Bronk Ramsey, C.; Dee, M.; Lee, S.; Nakagawa, T.; and Staff, R.A. Developments in the calibration and modeling of radiocarbon dates. Radiocarbon 2010, 52 (2-3), 953-961.

[11] Armbruster, B.; Parreira, R.; Eds. Inventário do Museu Nacional de Arqueologia. Coleç̧ão de ourivesaria. Do Calcolítico à Idade do Bronze. Lisboa: Instituto Português de Museus; 1993.

[12] Figueiredo, E. A study on metallurgy and corrosion of ancient copper-based artifacts from the Portuguese territory, 2010, unpubl. Thesis Univ. Lisboa, 59, tab.3.4, n. 983.299.163.

[13] Carreira, J.R. Pré-história Recente do Abrigo Grande das Bocas. Trabalhos de Arqueologia da EAM 1994, 2, 47-144.

[14] Teržan, B.; Lo Schiavo, F.; Trampuž, N. Most na Soçi (S. Lucia) II, III, Katalogi in Mnografije: Ljubljana, 1985.

[15] Giumlia-Mair, A. Evoluzione tecnica e formale nella produzione di fibule e spilloni tra il IX e il IV sec. a.c. nell'area Alpino-Orientale. In Fibulae. Dall'età del bronzo all'alto Medioevo, tecnica e tipologia, Formigli, E. Ed.; Antquarium di Poggio Civitate: Murlo, 2003; $49-58$.

[16] Pedro, I. O Povoamento Proto-histórico na região de Viseu unpubl. Thesis Univ. Porto, Porto, 1995, 141, Est. LXI, 6,7, 8 and 9.

[17] Heynowski, R. Nadeln, erkennen bestimmen beschreiben. München: Deutscher Kunstverlag, 2014; 58.

[18] Heynowski, R. Nadeln, erkennen bestimmen beschreiben. München: Deutscher Kunstverlag, 2014; 58.

[19] Heynowski, R. Nadeln, erkennen bestimmen beschreiben, München: Deutscher Kunstverlag, 2014; 53.

[20] Kerouatan, I. La production métallique des stations littorals imergées du Lac du Bourget (Savoie) à l'Âge du Bronze Final. In L'atelier du bronzier en Europe $d u X X^{e}$ au VIII siècleavant notre ère. Production, circulation et consummation du bronze CTHS: Paris, 1998; vol. 3, p. 87-102, p. 93, fig.4 n. 6.

[21] Vilaça, R. Aspectos do Povoamento da Beira Interior (Centro e Sul) nos Finais da Idade do Bronze. Lisboa: IPPAR, 1995; 341.

[22] Hahn-Weinheimer, P.; Hirner, A.; Weber-Diefenbach, K. Röntgenfluoreszenzanalytische Methoden - Grundlagen und praktische Anwendung in den Geo-, Material und Umweltwissenschaften, Vieweg Verlag: Braunschweig, Wiesbaden, 1995.

[23] Lutz, J.; Pernicka, E. EDXRF analysis of ancient copper alloys. Archaeometry 1996, 38 (2), 313-323.

[24] Giumlia-Mair, A.; Kassianidou, V.; Papasavvas, G. Miniature ingots from cyprus. In Metallurgy: Understanding How, Learning Why: Studies in Honor of James D. Muhly; Betancourt, P.P. Ferrence, S.C. Eds.; Prehistory Monographs, INSTAP Press: Philadelphia, 2011; 11-19.

[25] Giumlia-Mair, A. Composition of the Mochlos Sistrum, Appendix to: Soles J., The Mochlos Sistrum and its origins. In Metallurgy: Understanding How, Learning Why: Studies in Honor of James D. Muhly; Betancourt, P.P. Ferrence, S.C. Eds.; Prehistory Monographs, INSTAP Press: Philadelphia, 2011; 131-144.

[26] Rehren, Th.; Boscher, L.; Pernicka, E. Large scale smelting of speiss and arsenical copper at an Early Bronze Age Arisman, Iran. Journal of Archaeological Science 2012, 39, 1717-1727.

[27] Ferrence, S.; Giumlia-Mair, A. Bronze Age metal objects from East Crete, Greece. In Proceedings of the 8th Conference of the Beginning of the Use of Metals and Alloys (BUMA 8), Cultural Interaction and the Use of Metals, September 10-15 2013; Nagata, K., Izawa, E., Yamasue, E. Eds.; Nara: Japan, 2014; 301-309.

[28] Giumlia-Mair, A.; Ferrence, S.C.; Betancourt, P.P. Metallurgy of the copper-based objects from Gournia, east Crete, in Archaeometallurgy in Europe III. In Proceedings of the 3rd International Conference, Deutsches Bergbau-Museum Bochum, June 29July 1, 2011; Hauptmann, A. Modarressi-Tehrani, D. Eds.; 2015; 145-153.

[29] Armbruster, B.; Parreira, R. Eds. Inventário do Museu Nacional de Arqueologia. Colecção de ourivesaria. Do Calcolítico à Idade do Bronze. Lisboa: Instituto Português de Museus, 1993.

[30] Burgess, C.; Coombs, D.; Eds. Bronze Age Hoards. Some Finds Old and New; BAR: Oxford, 1979; 76. 
Copyright of Materials \& Manufacturing Processes is the property of Taylor \& Francis Ltd and its content may not be copied or emailed to multiple sites or posted to a listserv without the copyright holder's express written permission. However, users may print, download, or email articles for individual use. 